\title{
Late Holocene environmental change in arctic western Siberia
}

\author{
Angela E Self,' 'Vivienne J Jones ${ }^{2}$ and Steve J Brooks'
}

\begin{abstract}
The Putorana Plateau, western Siberia, situated on the boundary of the Atlantic and continental Siberian climate provinces, is sensitive to shifts in atmospheric circulation. Three lakes on an altitudinal transect were studied using chironomid subfossils to provide the first estimates of late Holocene climate in this remote, poorly studied region of Arctic Russia. The analysis of sediment cores from three closely located lakes is rare in palaeoenvironmental studies and enables the role of other environmental variables, which may be a potential source of error in palaeoclimatic reconstructions, to be assessed. The chironomid-based reconstructions suggest a more maritime climate c. $3400 \mathrm{cal}$. BP with July temperatures $\mathrm{c}$. I. $5^{\circ} \mathrm{C}$ warmer than present which cooled rapidly by c. $2^{\circ} \mathrm{C}$, with a more continental climate between 3200 and $2600 \mathrm{cal}$. BP. These trends are similar in timing and scale to other northern hemisphere records. The recent chironomid records from all three lakes show pronounced faunal changes over the last 50 years probably directly or indirectly because of climate-driven changes in catchment hydrology. This is particularly evident in the recent record from an open lake within a large wetland habitat, which appears relatively insensitive to changes in July air temperatures.
\end{abstract}

\section{Keywords}

chironomids, climate, continentality, Holocene, Putor, Russia

Received 23 May 20I4; revised manuscript accepted 23 June 2014

\section{Introduction}

The Arctic region, north of $60^{\circ} \mathrm{N}$, has warmed approximately twice as fast as the global mean since AD 1875 (Bekryaev et al., 2010), and this trend is projected to continue in the 21 st century (IPCC, 2013). Increasing surface temperatures, melting permafrost, enhanced precipitation and changes in atmospheric circulation are expected to cause changes in the physical, chemical and biological properties of arctic lakes and their catchments (Arctic Climate Impact Assessment (ACIA), 2004). The Putorana Plateau, western Siberia, (Figure 1) lies on the boundary between the Atlantic and the continental Siberian climate provinces (Shahgedanova, 2002). The climate of the European arctic and sub-arctic is ameliorated by cyclonic activity and warm oceanic currents from the Atlantic, whereas the continental province of central Siberia is characterised by an extreme continental climate and aridity (Przybylak, 2003). The climate on the Plateau is sensitive to shifts in the relative strengths of atmospheric circulation systems, particularly the Icelandic Low and Siberian High pressure systems. Cyclonic activity from the Atlantic results in reduced climate continentality in western Russia compared with the same latitudes further east. Continentality is an important factor in determining the length of the growing season and ice-free period, factors which influence both intra-lake and catchment characteristics and processes (Giesecke et al., 2008; Prowse et al., 2006; Salonen et al., 2012). On Milankovitch timescales, continentality is influenced by changes in solar insolation, sea-level and sea-ice extent, but over the last thousand years, changes in continentality should reflect major changes in atmospheric circulation (Mayewski et al., 2004; Meeker and Mayewski, 2002).

Chironomid midges (Insecta, Diptera, Chironomidae) are sensitive indicators of environmental conditions (Lindegaard, 1995).
Their distribution is influenced by many factors including the trophic status (Brundin, 1958), water depth (Heiri, 2004) and hypolimnetic oxygen conditions (Quinlan and Smol, 2001) of the lake in which their aquatic larvae complete their development. However, analysis of present-day assemblage data from lake surface sediments have shown mean summer air temperature to be the dominant factor determining chironomid distribution over wide geographical regions (e.g. Brooks and Birks, 2001; Eggermont and Heiri, 2012; Larocque et al., 2001). This reflects the dominant direct influence of temperature on chironomid life-cycles. The strength of the relationship has enabled the development of quantitative chironomid-inferred temperature inference models which have been used to reconstruct past temperatures in Western Europe and North America (see reviews in Brooks, 2006; Eggermont and Heiri, 2012; Walker and Cwynar, 2006) and more recently from northern Russia (Nazarova et al., 2011; Self et al., 2011). Although chironomid-based reconstructions have generated meaningful reconstructions for the broad-scale temperature variability of the Late Glacial and the transition to the Holocene (Lang et al., 2009; Lotter et al., 2012), the reproducibility of temperature reconstructions for the Holocene has been more ambivalent (Brooks et al., 2012; Velle et al., 2010, 2012). In some lakes,

'Natural History Museum, UK

¿University College London, UK

Corresponding author:

Angela E Self, Department of Life Sciences, Natural History Museum, Cromwell Road, London SW7 5BD, UK.

Email: A.Self@nhm.ac.uk 
(a)

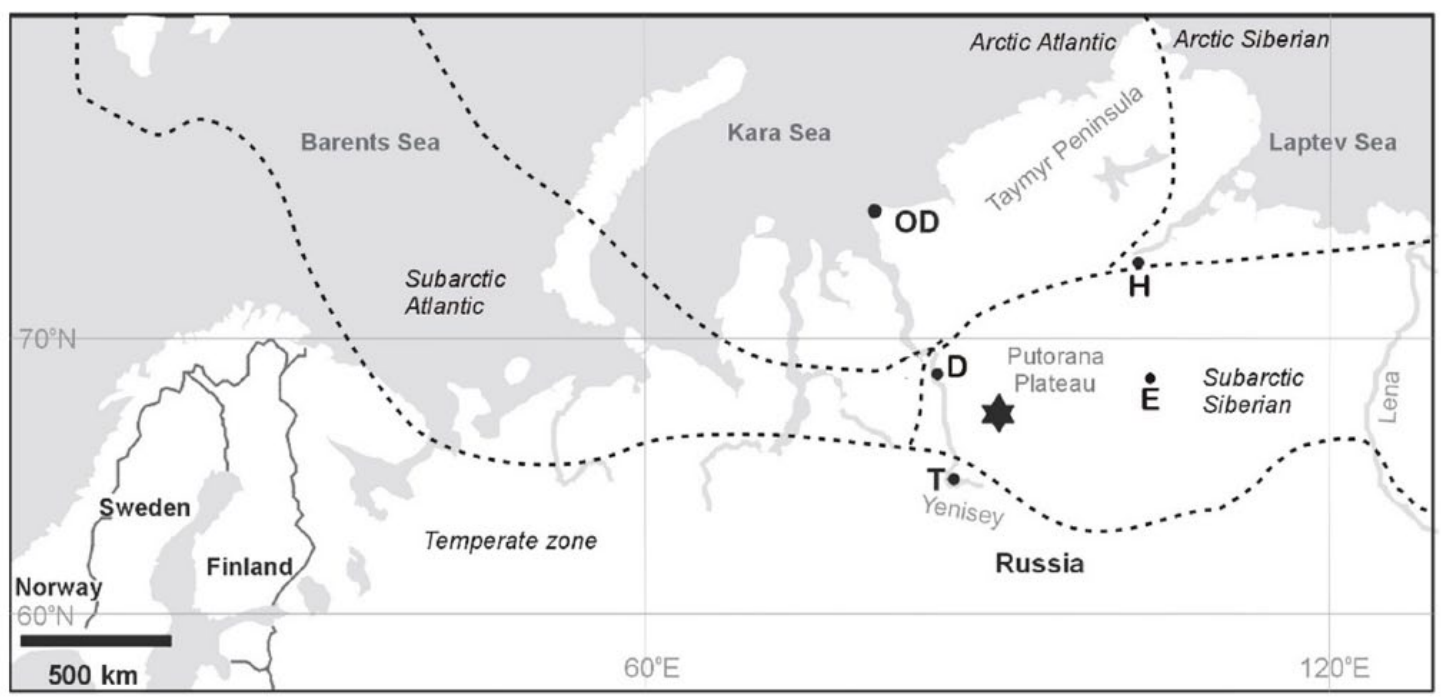

(b)

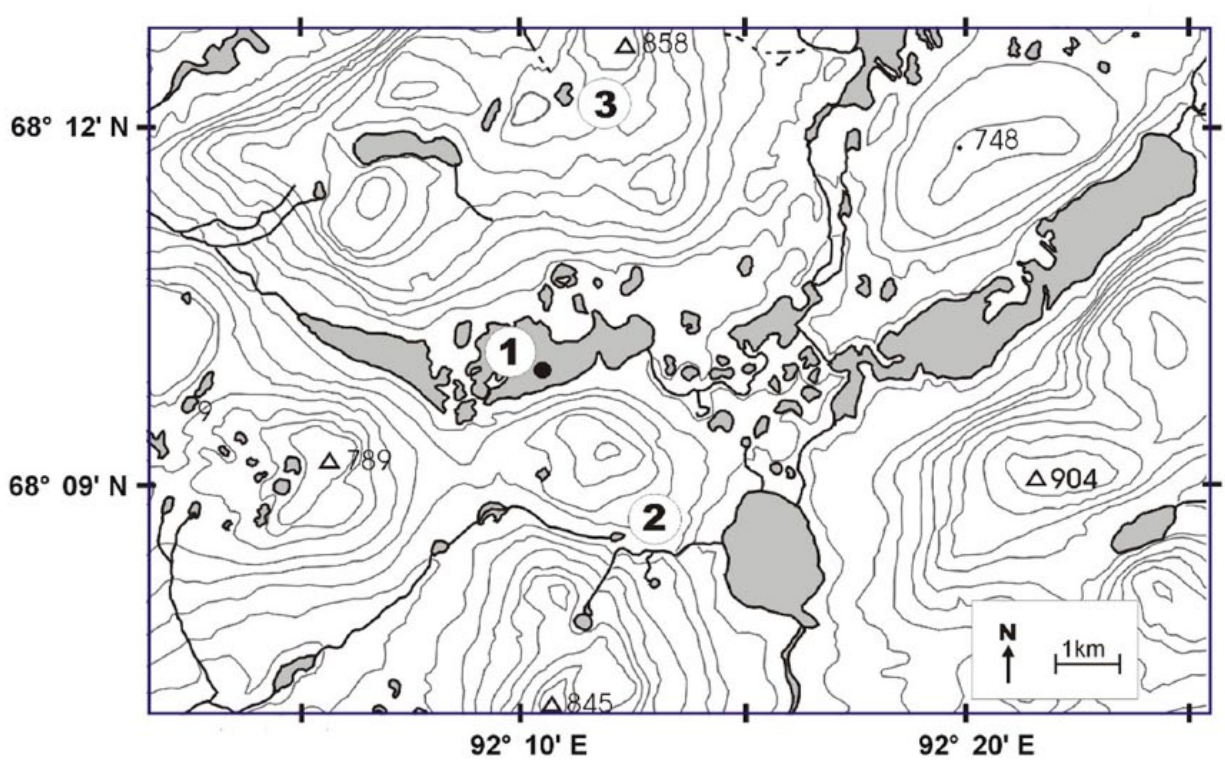

Figure I. (a) Location of the study site (star) on the Putorana Plateau in western Siberia. The towns marked are OD: Ostrov Dikson; H: Hatanga; D: Dudinka; E: Essej; and T:Turuhansk. Boundaries of the Arctic and Sub-Arctic climatic provinces are marked by dashed lines with names in italics. (b) The location of the cored lakes ( $\mathrm{I}=\mathrm{GYXO}, 2=\mathrm{PONE}, 3=\mathrm{PTHE})$ and topography of their catchments. The coring site at GYXO is marked with a black point.

chironomids may be responding to variables other than the relatively small-scale Holocene summer temperature fluctuations (Berntsson et al., 2014), and therefore, such reconstructions may be inappropriate (Huntley, 2012). In this study, the analysis of three lakes situated in close proximity offers an opportunity to separate site-specific variation from the regional climate signal.

\section{Study site}

The Putorana Plateau is the highest part of a large igneous province, the Siberian Traps, which lies between the River Yenisey and River Lena in western Siberia (Nalvikin, 1973; Figure 1). The bedrock consists of thick horizontal basalt dissected by deep valleys with numerous rivers and freshwater bodies. Soil cover is thin and rocky with a thin layer of organic material near the surface. The remoteness of the Putorana Plateau has contributed to the survival of a number of rare and endemic animal species (Webber and Klein, 1977).

The Putorana Plateau has a sub-arctic alpine flora comprising mountainous open Larix woodland, alpine tundra and polar desert (Shahgedanova et al., 2002). Within the study area, the treeline occurs at approximately 500-600 m.a.s.l. Sediment cores were obtained from three lakes selected to reflect the differing altitudes and habitats on the Plateau (Table 1). Lake Glukhoe (code-named GYXO) is a large lake within a river valley - wetland environment (altitude 569 m.a.s.1.; Figure 1b). The lake is formed of two basins, and water depth decreases to under $0.5 \mathrm{~m}$ at the narrowest point. The lake sediments were cored in the western basin. The second lake (code-named PONE) is situated in a hanging valley between two NW-SE orientated mountain ridges (altitude 596 m.a.s.l.) and has a single outflow stream to the northwest. The vegetation around GYXO and PONE consists of scattered Larix sibirica and Larix gmelinii with an understorey of Alnus viridis and Betula nana. Salix species are common on wetter areas. The third lake (code-named PTHE) was the highest altitude lake sampled (805 m.a.s.1.), located in a small rocky hollow below a $858-\mathrm{m}$ summit. Inflow to the lake is derived from precipitation and melt-water from widespread snow beds and the active layer of permafrost. The groundcover is predominately bare rock and talus slopes. 
Table I. Summary characteristics of the lakes with details of the cores.

\begin{tabular}{llll}
\hline Variable & PONE & PTHE & GYXO \\
\hline Latitude & $068^{\circ} 08^{\prime} 33^{\prime \prime} \mathrm{N}$ & $068^{\circ} 12^{\prime} 12^{\prime \prime} \mathrm{N}$ & $068^{\circ} 09^{\prime} 54^{\prime \prime} \mathrm{N}$ \\
Longitude & $092^{\circ} 12^{\prime} \mathrm{II} \mathrm{I}^{\prime \prime} \mathrm{E}$ & $092^{\circ} 10^{\prime} 44^{\prime \prime} \mathrm{E}$ & $092^{\circ} 10^{\prime} 23^{\prime \prime} \mathrm{E}$ \\
Altitude (m.a.s.l.) & 596 & 805 & 569 \\
Area of lake (ha) & 0.9 & 6.3 & 230 \\
Area of catchment (ha) & 16 & 71 & 2000 \\
Maximum lake depth (m) & 5 & 3.9 & 13 \\
pH & 7.7 & 7.28 & 7.28 \\
Conductivity (uS) & 27 & 19 & 22 \\
Secchi depth (m) & 4.2 & To bottom & 5.15 \\
Sampling date & 05 July 2006 & 07 July 2006 & 01 July 2006 \\
Core length (cm) & 28 & 34 & 33 \\
Sampling resolution of & $0-20 \mathrm{~cm}$ at $0.25-\mathrm{cm}$ intervals; & $0-20 \mathrm{~cm}$ at $0.25-\mathrm{cm}$ intervals; & $0-33 \mathrm{~cm}$ at $0.25-$ \\
sediment core & $20-28 \mathrm{~cm}$ at $0.5-\mathrm{cm}$ intervals & $20-34 \mathrm{~cm}$ at $0.5-\mathrm{cm}$ intervals & $\mathrm{cm}$ intervals \\
\hline
\end{tabular}

The sparse vegetation includes prostrate willows less than $10 \mathrm{~cm}$ high and lichens.

This is the first study to examine lake ecosystems and aquatic invertebrates on the Plateau and has the following aims:

- To use short cores from three lakes on an altitudinal gradient to provide replicated estimates of chironomid-inferred past July air temperatures and continentality for the late Holocene,

- To compare these palaeoclimate estimates with independent instrumental and proxy climate records,

- To examine the role of site-specific characteristics in influencing the chironomid-based reconstructions.

\section{Materials and methods}

The bathymetry of the lakes was initially assessed by making transects of the lakes and measuring the water depth, at timed intervals, using a hand-held echo sounder. Sediment cores were collected from the deepest point of each lake, all deeper than $2 \mathrm{~m}$ to minimise the risk of cryogenic disturbance of the sediments, using a 70-mm diameter HON-Kajak corer (Renberg, 1991) with a $0.5-\mathrm{m}$ Perspex coring tube. The cores were extruded in the field at $0.25-$ to $1.0-\mathrm{cm}$ intervals and the samples subsequently stored in sealed plastic bags at $4^{\circ} \mathrm{C}$ in the dark.

\section{Dating}

Three bulk sediment samples from each core were radiocarbondated by AMS analysis in the NERC Radiocarbon Facility (Environment) and SUERC AMS Laboratory (allocation number 1746.1013) and an additional sample from the base of the GYXO core $(31.75-32.00 \mathrm{~cm})$ by Beta-Analytical, USA. Samples were dried, sieved to $<180 \mu \mathrm{m}$ and acid-washed to remove carbonates. The total organic carbon was recovered as $\mathrm{CO}_{2}$ through combustion, then converted to $\mathrm{CO}$ in the presence of zinc and further reduced to graphite by iron reduction. Bulk sediment was dated as there was insufficient macrofossil material. Dates were calibrated using IntCal13 (Reimer et al., 2013) in Clam 2.2 (Blaauw, 2010). The top $4-8 \mathrm{~cm}$ of each core were also dated by ${ }^{137} \mathrm{Cs} /{ }^{210} \mathrm{~Pb}$ analysis. Dried sediment samples were analysed for ${ }^{210} \mathrm{~Pb},{ }^{226} \mathrm{Ra},{ }^{137} \mathrm{Cs}$ and ${ }^{241} \mathrm{Am}$ by direct gamma assay in the Bloomsbury Environmental Isotope Facility (BEIF) at University College London. Radiometric dates were calculated using the Constant Rate of Supply (CRS) dating model (Appleby, 2001) and corrected using the AD 1963 depths determined from the ${ }^{137} \mathrm{Cs} / 210 \mathrm{~Pb}$ stratigraphic record. Age-depth models were produced in the $\mathrm{R}$ statistical software (R Development Core Team, 2013) using Clam 2.2 (Blaauw,
2010). All calibrated radiocarbon dates are given in years before present (AD 1950), abbreviated 'cal. BP'.

\section{Chironomid analyses}

Sediment samples for subfossil analysis were prepared at sample intervals of between 1 and $2 \mathrm{~cm}$ using standard methods (Brooks et al., 2007). Between 41 and 300 head capsules were separated and mounted in Euparal ${ }^{\mathrm{TM}}$ mounting medium after progressive dehydration in $80 \%$ and $100 \%$ ethanol. Chironomids were identified with reference to Wiederholm (1983), Rieradevall and Brooks (2001), Brooks et al. (2007) and the national Chironomidae collection at the Natural History Museum, London, UK.

\section{Data analysis}

The chironomid stratigraphies were zoned by optimal sum-ofsquares partitioning using the ZONE program, version 1.2 (Juggins, 1991) and the statistical significance of the zones assessed by comparison with a broken-stick model BSTICK (Bennett, 1996) using the program BSTICK v. 1 (Line and Birks, unpublished). Detrended correspondence analysis (DCA) was initially undertaken on chironomid relative abundance data from each of the three cores to establish the magnitude of species turnover. The chironomid assemblages were also plotted passively in a Canonical Correspondence Analysis (CCA) of the modern Russian data set (DCA axis 1 gradient length $=2.6$ S.D) to explore the relationship between changes in faunal assemblages and the environmental variables. In DCA and CCA ordinations, species data were square-root transformed to stabilise species variance and rare species were down-weighted. All ordination analyses were undertaken using CANOCO 4.5 (Ter Braak and Smilauer, 2002).

Chironomid-inferred mean July air temperatures (C-IT $\left.{ }_{\text {July }}\right)$ were estimated by applying an 81-lake inference model based on a modern Russian calibration set (Self et al., 2011). In addition, chironomid-inferred continentality indices (C-IC) were estimated using a 149-lake inference model based on a combined modern Norwegian-Russian calibration set (Self et al., 2011). The Norwegian lakes were included in the modern continentality calibration set to maximise the length of the continentality gradient. This provides the best basis for reliable estimates of the continentality optimum of each chironomid taxon and also covers the full range of continentality values that may have occurred at the study site during the period being studied. This approach minimises possible extrapolation of inferred values, reduces possible 'edge effects' of inferred values which are close to the limits of the modern calibration set being under- or over-estimated and maximises the possibility of good modern analogues for the fossil chironomid assemblages. The Gorcynzski continentality index (CI) used 
is derived from the annual temperature range and latitude (Grieser et al., 2006). Chironomid percentage abundance data were squareroot transformed. Both models were developed using weighted averaging partial least squares (WA-PLS) regression with two components. Reconstructions were bootstrapped with 999 iterations to provide sample specific errors of prediction (SSEP). The significance of the reconstructions was evaluated using the palaeoSig package (Telford, 2011) in R (R Development Core Team, 2013) with 999 random reconstructions. Following Telford and Birks (2011), a reconstruction is considered statistically significant if it explains more of the variance in the fossil data than $95 \%$ of reconstructions that are derived from random environmental variables.

\section{Results}

\section{Chronologies}

All three cores are composed of homogeneous gyttja with little identifiable structure. The ${ }^{210} \mathrm{~Pb}$ chronology provided an agedepth profile for the recent part of the sequence with the basal date used to constrain the age-depth model based on ${ }^{14} \mathrm{C}$ dates. Because of the relatively low numbers of ${ }^{14} \mathrm{C}$ dates, age-depth models were fitted by linear intrapolation using the $\mathrm{R}$ Clam package of Blaauw (2010).

In total, 11 samples from PONE were ${ }^{210} \mathrm{~Pb}$ dated and 3 samples were AMS ${ }^{14} \mathrm{C}$ dated. Calibrated ${ }^{14} \mathrm{C}$ dates of bulk sediment samples from 14.5 to $27 \mathrm{~cm}$ depth (Figure 2a; Supplementary Material 1, Table a, available online) show considerable overlap and age-reversals suggesting that the basal section of the core has been disturbed and is unsuitable for time-dependent comparisons. However, the ${ }^{210} \mathrm{~Pb}$ chronology of the uppermost $7.5 \mathrm{~cm}$ indicates a period of continuous deposition over the last 120 years with a modern age for the top of the sediment. Sediment accumulation rates decline with depth from 0.14 to $0.03 \mathrm{~cm} \mathrm{yr}^{-1}$.

In total, 16 samples from PTHE were ${ }^{210} \mathrm{~Pb}$ dated and 3 samples were AMS ${ }^{14} \mathrm{C}$ dated (Figure $2 \mathrm{~b}$ ). The peaks in ${ }^{137} \mathrm{Cs}$ and ${ }^{241} \mathrm{Am}$ activities are above the depth calculated using CRS and CIC (Constant Initial Concentration) dating models (Appleby, 2001). The CRS model places the AD 1963 layer, recording the fallout maximum from atmospheric testing of nuclear weapons, closer to the radionuclide markers than the CIC model which suggests the CRS model is more valid. The ${ }^{210} \mathrm{~Pb}$ chronology of the core was calculated using the CRS model and corrected using ${ }^{137} \mathrm{Cs}$ and ${ }^{241} \mathrm{Am}$ records (Supplementary material 1, Table b, available online). The corrected results show that post-AD 1963 ${ }^{210} \mathrm{~Pb}$ flux is approximately $40 \%$ of that in pre-AD 1963 section and suggests that part of the recent sedimentary sequence, that is, above $1.75 \mathrm{~cm}$, is absent from the core. Whereas PONE and GYXO show sediment accumulation rates declining with depth, PTHE shows an abrupt decline between 2.5 and $1.5 \mathrm{~cm}$. Part of the sequence at this depth may be absent because of a period of non-accumulation or disturbance. Because of the uncertainty in dating, results from the top $2 \mathrm{~cm}$ of PTHE were excluded from $\mathrm{C}$-I reconstructions. Below $4.5 \mathrm{~cm}$ depth in the ${ }^{210} \mathrm{~Pb}$ record, sediment accumulation stabilises at $0.04-0.05 \mathrm{~cm} \mathrm{yr}^{-1}-$ this is an order of magnitude greater than the rates between 3900 and 2100 cal. BP, suggesting sediment accumulation has increased at some time since $2100 \mathrm{cal}$. BP.

In total, 14 samples from GYXO were ${ }^{210} \mathrm{~Pb}$ dated and 4 samples were AMS ${ }^{14} \mathrm{C}$ dated (Figure $2 \mathrm{c}$ ). The ${ }^{210} \mathrm{~Pb}$ chronology (Supplementary Material 1, Table c, available online) of the uppermost $4.5 \mathrm{~cm}$ suggests continuous deposition of the sediment with sediment accumulation rates gradually declining from 0.09 to $0.007 \mathrm{~cm} \mathrm{yr}^{-1}$ over the last 150 years. One radiocarbon date at $26.25-26.5 \mathrm{~cm}$ depth was regarded as too young. Agreement indices calculated by OxCal (Bronk Ramsey, 2009) for the samples at 19 and $26.25 \mathrm{~cm}$ depth were $60 \%$ and $39 \%$, respectively. Bronk
Ramsey (2009) states rejection should be considered if the index falls below $60 \%$. Excluding the date at $26.25 \mathrm{~cm}$ depth increased the overall agreement index of the model $\mathrm{A}_{\text {model }}$ from $59 \%$ to $97 \%$, above the $60 \%$ threshold indicating no further samples need to be rejected. Holocene sediment accumulations rates, excluding the sample at $26.25 \mathrm{~cm}$ depth, compare well with those obtained for the basal ${ }^{210} \mathrm{~Pb}$ record. The basal ${ }^{14} \mathrm{C}$ age obtained from GYXO is similar to the PTHE age from a similar depth (Figure 2; Supplementary Material 1, available online) with similar rates of sediment accumulation in the early part of both records.

\section{Chironomid analysis}

Corynocera ambigua and Corynocera oliveri-type occurred in the majority of samples and were particularly abundant in PONE and PTHE, reaching more than $20 \%$ in some samples. The high abundances of these taxa in the Putorana lakes makes them distinct from modern assemblages from lakes in Norway, north-east European Russia and western Siberia (Self et al., 2011). The remaining modern Putorana fauna, which includes Chironomus anthracinus-type, Sergentia coracina-type, Procladius, Micropsectra spp., Tanytarsus lugens-type and other Tanytarsini species, is typical of relatively cool July air temperatures $\left(8-12^{\circ} \mathrm{C}\right.$; Self et al., 2011).

PONE. A total of 62 taxa were identified in the 17 samples analysed from PONE core (Figure 3); of these, 20 taxa were represented by one or two specimens only. These rare taxa, which include Thienemanniella clavicornis-type, Rheocricotopus and Rheotanytarsus, are typically found in streams or rivers (Cranston et al., 1983; Pinder and Reiss, 1983). An unidentified Diamesinae and Trichotanypus posticalis form minor components of the assemblages. Trichotanypus posticalis is found among mosses in running or standing water across northern regions of the Holarctic (Brundin, 1983). The mentum of the unidentified Diamesinae species is similar to Diamesa aberrata-type, but narrower and has eight lateral teeth and five broad median teeth, which become shorter towards the middle of the mentum.

Taxa associated with flowing water occur intermittently throughout zone PO-1, for example, Thienemanniella clavicornistype, Rheocricotopus (at $27.75 \mathrm{~cm}$ depth) and Rheotanytarsus (at $12-8 \mathrm{~cm}$ depths). Profundal taxa, including Heterotrissocladius maeaeri-type and Stictochironomus, decline towards the top of zone PO-1 and are absent from zone PO-2. Radiocarbon dating suggests the lower part of the core may have been subject to extensive disturbance of the sediment. The absence of profundal species and taxa associated with flowing water in zone PO-2 suggests the zone boundary at $3.75 \mathrm{~cm}$ (AD 1970) may mark a change in hydrology so that episodes of high lake level and valley flooding became less frequent. Many of the cold stenothermic taxa (e.g. Paracladius and Micropsectra insignilobus-type) decline and disappear over the last 100 years (from $6.5 \mathrm{~cm}$ ). Increases in Corynocera ambigua, Paratanytarsus penicillatus-type and Zalutschia zalutschicola-type from $8 \mathrm{~cm}$ may indicate an expansion in macrophytes and/or shift to more humic conditions.

PTHE. A total of 53 taxa were identified in the 19 samples analysed from PTHE core (Figure 4). The composition differs from the other two cores because of the presence of Psectrocladius sordidellus-type at 9-19\% abundance compared with less than 5\% in GYXO and PONE. Although Psectrocladius sordidellustype is acid tolerant (Pinder and Morley, 1995), the observed $\mathrm{pH}$ is circum-neutral (Table 1), and therefore, its occurrence in PTHE may be associated with the growth of macrophytes in the littoral zone (Brodersen et al., 2001; Brooks et al., 2007). The lake is gently shelving resulting in an extensive littoral within the photic zone suitable for the growth of macrophytes. Corynocera ambigua 

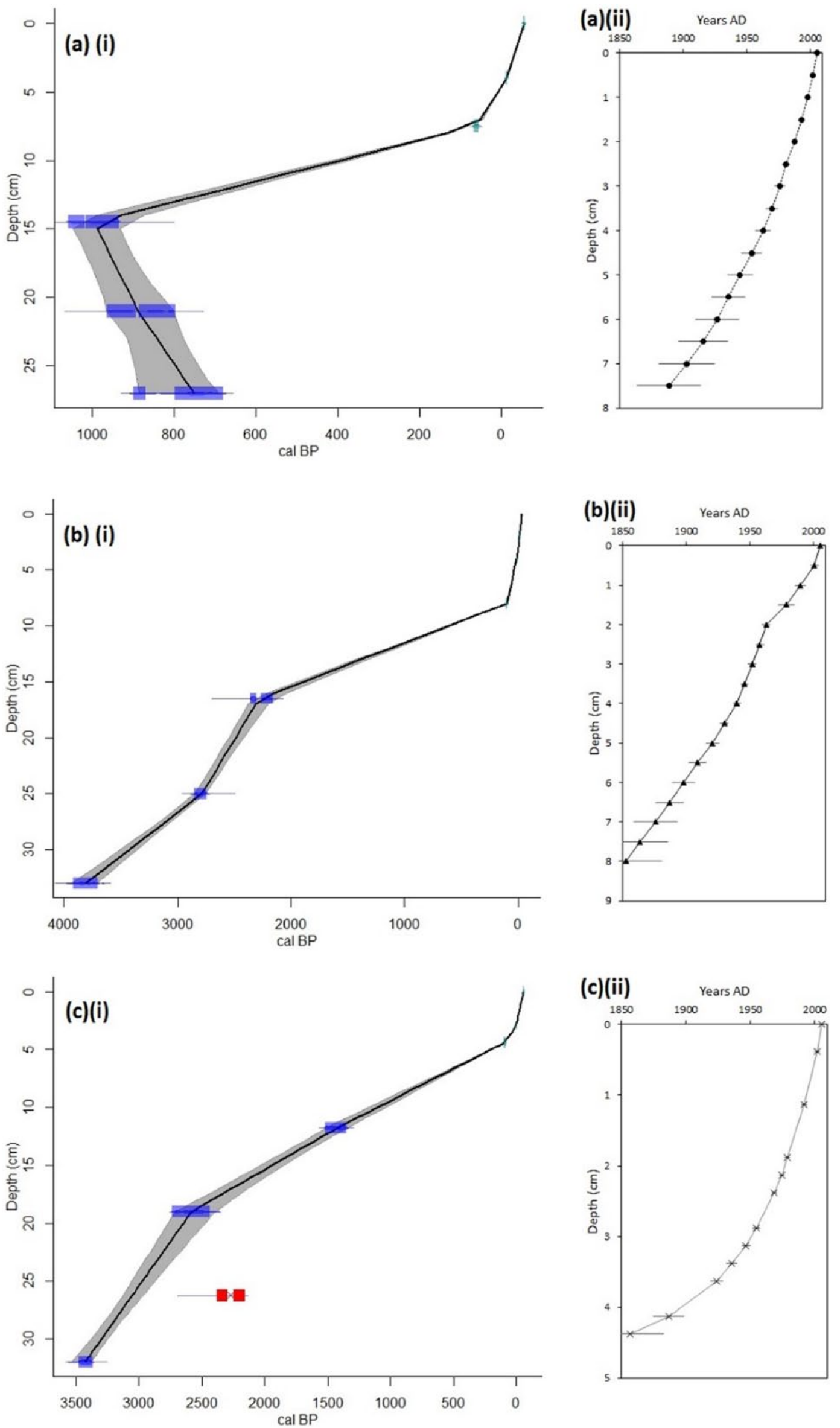

Figure 2. Age-depth models for (a) PONE, (b) PTHE and (c) GYXO constructed based on (i) ${ }^{14} \mathrm{C}$ ages and (ii) ${ }^{210} \mathrm{~Pb}$ dating of the top sediment. One rejected ${ }^{14} \mathrm{C}$ date for $\mathrm{GYXO}$ is shown. Inserts (ii) show age-depth models based on ${ }^{210} \mathrm{~Pb}$ dating at higher resolution. 


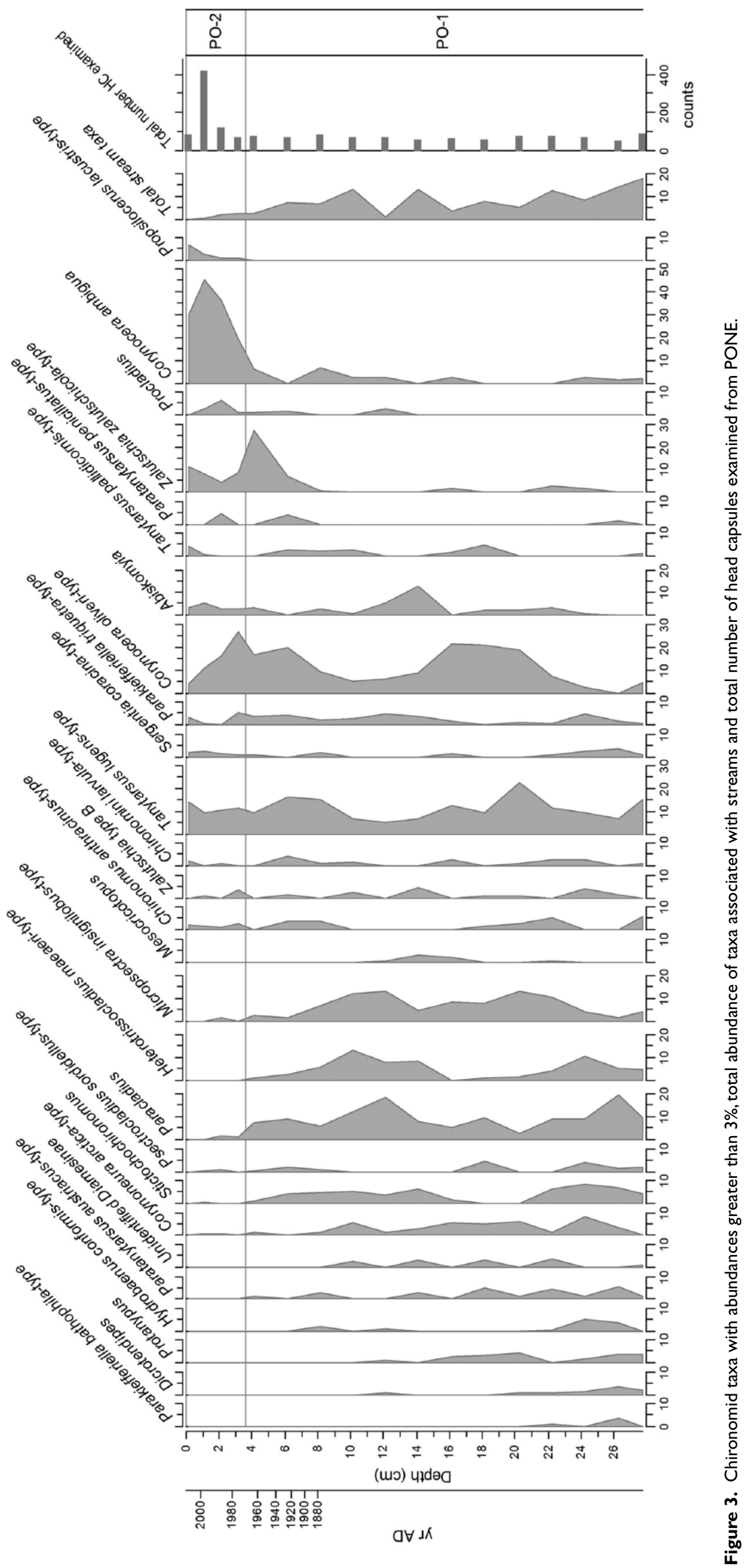




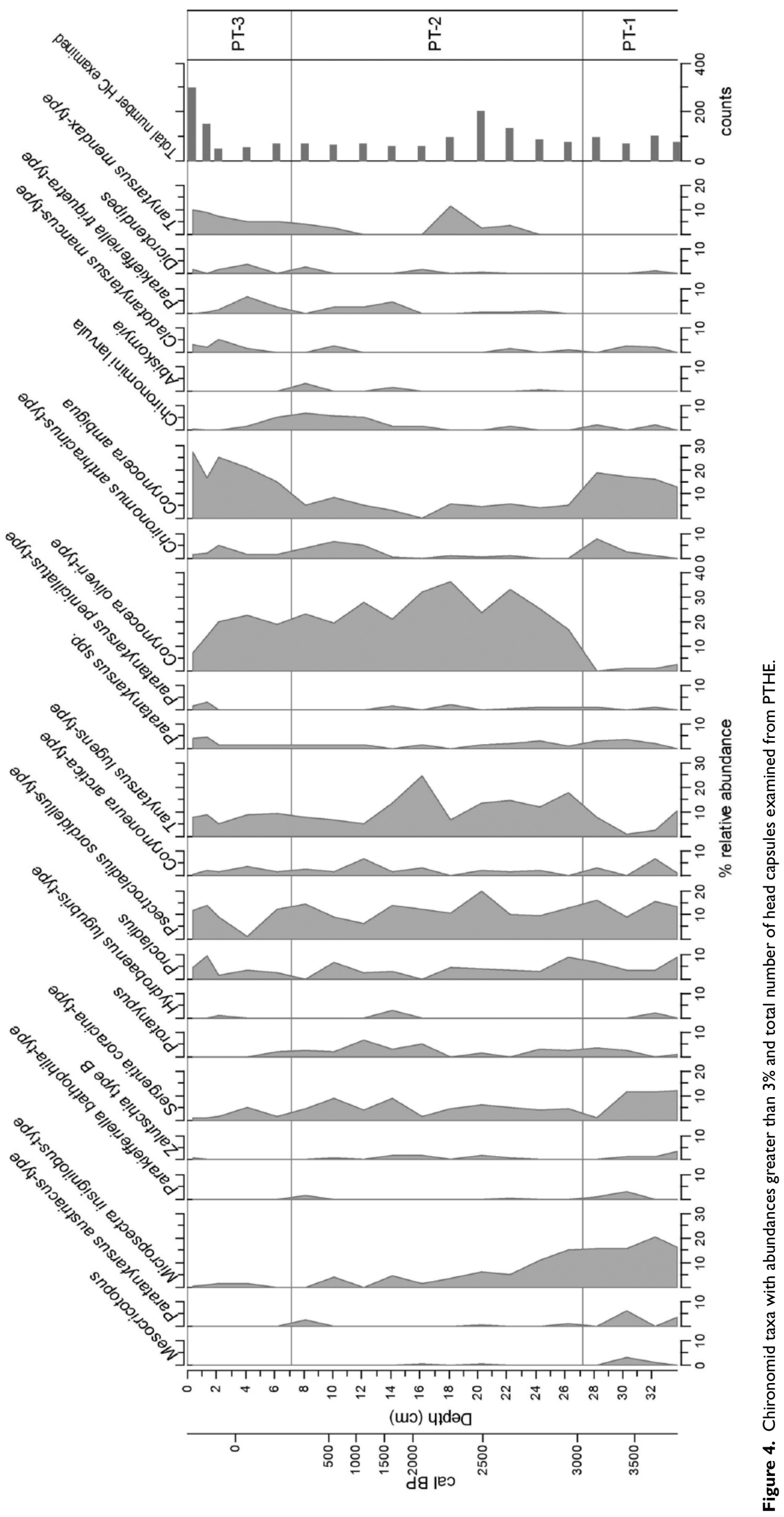


and Corynocera oliveri-type frequently dominate the subfossil assemblages with maximum abundances of $27.3 \%$ and $36.5 \%$, respectively.

Initially (34.0-27.0 cm; 3900-3000 cal. BP), the assemblage is dominated by Micropsectra insignilobus-type, Sergentia coracina-type and Corynocera ambigua. These taxa decline in abundance from $28 \mathrm{~cm}$ (c. $3200 \mathrm{cal}$. BP), and Corynocera oliveri-type and Tanytarsus lugens-type, which have lower temperature optima, increase, suggesting a decline in summer temperatures. Tanytarsus mendax-type first appears at $22 \mathrm{~cm}$ (2600 cal. BP) and increases to a maximum of $12 \%$ at $17.25 \mathrm{~cm}$. This taxon is indicative of warmer, more productive lakes than Tanytarsus lugens-type (Brooks et al., 2007). From $10 \mathrm{~cm}$ (c. 600 cal. BP), increases in thermophilic taxa such as Tanytarsus mendax-type, Chironomus anthracinus-type and Dicrotendipes suggest gradual climate warming and/or increasing lake productivity. The abundance of Corynocera ambigua also increases from $8 \mathrm{~cm}(\mathrm{AD} 1850)$.

GYXO. Lake GYXO is larger and deeper than the other two study lakes (Table 1), although it was not thermally stratified when sampled (surface water temperature $6.2^{\circ} \mathrm{C}$ and bottom temperature $5.8^{\circ} \mathrm{C}$ ). A total of 55 taxa were identified in the 20 samples analysed from core GYXO (Figure 5). Of these, 16 taxa were represented by one or two specimens only. These rare taxa include Synorthocladius associated with flowing water (Cranston et al., 1983), and genera such as Pseudosmittia and Smittia, which include many terrestrial or semi-terrestrial species (Cranston et al., 1983; Strenzke, 1950). The composition differs from the other two lakes because of the lower abundance of Corynocera ambigua and Corynocera oliveri-type.

Taxa indicative of relatively warm conditions, such as Tanytarsus mendax-type and Tanytarsus pallidicornis-type, are most abundant at the base of the core (33-20 cm; 3500-2700 cal. BP). From $2700 \mathrm{cal}$. BP, these decline and the fauna is dominated by cold stenotherms such as Micropsectra insignilobus-type and Sergentia coracina-type. These decline towards the top of zone G-2 and from $500 \mathrm{cal}$. BP are replaced by other cold stenotherms, such as Thienemannimyia, Micropsectra radialis-type and Zalutschia type B.

\section{Time trajectories in CCA space}

Changes in the chironomid assemblages in the down-core samples were compared with the modern environmental variables using CCA and the fossil assemblages plotted as supplementary passive samples. This analysis was used to produce time-tracks in modern CCA space showing the trajectory of the fossil samples against environmental variables which have a significant influence on changes in the modern assemblages (Figure 6). In CCA space, the lakes plot to the left on the first axis indicating relatively cold July air temperatures and, in general, the fossil assemblages from all three lakes are dominated by cold stenotherms. The trajectories suggest that temperatures at the base of the cores were similar to the present-day with cooler intervals during the middle of the sequences. The sequences from PONE and PTHE (Figures 6a and b) also show a general decline in axis 2 scores which is related to water depth and mean annual precipitation (MAP), suggesting the lakes were initially deeper than present and have become gradually shallower over time. At GYXO (Figures $6 \mathrm{c}$ and 7), axis 2 scores increased between 9.5 and $7.5 \mathrm{~cm}$ depth (1000-650 cal. BP) and are highest between 7.5 and $3.0 \mathrm{~cm}$ depth (650 cal. BP to AD 1970), suggesting a fauna more characteristic of deep lakes from wetter regions than the modern fauna. All three lakes show a change in CCA axis 2 scores between AD 1950 and AD 1965.

\section{Chironomid-inferred reconstructions}

The nearest meteorological station with long duration records, Turuhansk $\left(65.78^{\circ} \mathrm{N}, 87.93^{\circ} \mathrm{E}, 35\right.$ m.a.s.1.), is $320 \mathrm{~km}$ to the south and has records dating back to AD 1881. Mean July air temperatures, CIs and MAP are included in the figures to show recent trends, although the temperatures are warmer than those at the study site because of the more southerly and lower altitude location of Turuhansk. Shorter duration instrumental records are also available from Dudinka $\left(69.4^{\circ} \mathrm{N}, 86.1^{\circ} \mathrm{E}, 19\right.$ m.a.s.l.) and Essej $\left(68.46^{\circ} \mathrm{N}, 102.36^{\circ} \mathrm{E}, 271\right.$ m.a.s.l.); July and January air temperatures for the three study lakes were estimated by spatial interpolation of the mean of meteorological records from the three nearest weather stations for the 30 years preceding sampling (19762005), corrected for altitude (Self et al., 2011). Surface or near surface $\mathrm{C}^{-\mathrm{IT}_{\text {July }}}$ for GYXO $\left(11.8^{\circ} \mathrm{C}\right)$ and PTHE $\left(10.6^{\circ} \mathrm{C}\right)$ are within $0.1^{\circ} \mathrm{C}$ of the altitude-corrected value calculated from the meteorological data. The $\mathrm{C}$ - $\mathrm{IT}_{\text {July }}$ from the surface sediment of PONE $\left(11.2^{\circ} \mathrm{C}\right)$ is within $0.5^{\circ} \mathrm{C}$ of the calculated value, which is within the root-mean-square-error of prediction (RMSEP) of the inference model $\left( \pm 1.0^{\circ} \mathrm{C}\right)$. Similarly, estimated C-ICs are within the model error $( \pm 10)$ of the modern value calculated from the meteorological record (met); GYXO: met 55, C-I 46; PONE: met 55, C-I 54; PTHE: met 53, C-I 54.

For the pre-instrumental period (Figure 7a), C-I reconstructions from PTHE and GYXO show similar trends with a decline in C-IT July of approximately $2.0^{\circ} \mathrm{C}$ and an increase in C-IC continentality between 3200 and $2600 \mathrm{cal}$. BP. These changes are coincident with a decline in CCA axis 2 sample scores and a phase of high potassium ion deposition in the GISP2 ice core, a measure of

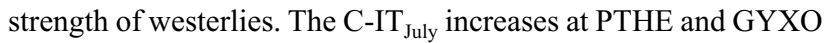
by $1^{\circ} \mathrm{C}$ c. $2400 \mathrm{cal}$. BP before declining to $10.7^{\circ} \mathrm{C}$. C-IT $\mathrm{July}_{\mathrm{y}}$ and $\mathrm{C}$-IC reconstructions for PTHE remain relatively stable throughout the remainder of the record, whereas at GYXO C-IT $\mathrm{July}_{\text {- }}$ increases and C-IC decreases between 1600 and $500 \mathrm{cal}$. BP. CCA axis 2 sample scores for PTHE decline again c. $600 \mathrm{cal}$. BP as GISP2 potassium ion concentrations increase. CCA sample scores increase in GYXO between 1000 and $650 \mathrm{cal}$. BP and so may predate the rise in potassium concentrations from $750 \mathrm{cal}$. BP.

Trends in C-IT and the instrumental record from Turuhansk are similar with cool periods indicated in both records at AD 1940 and $\mathrm{AD} 1976$ (Figure 7b). The approximately $6^{\circ} \mathrm{C}$ offset between the $\mathrm{C}-\mathrm{IT}_{\text {July }}$ reconstructions and the Turuhansk record arise from the more southerly and lower altitude location of the meteorological station. A rising trend indicated in PONE after AD 1960 is not reflected in the smoothed Turuhansk record, but the instrumental data show wide inter-annual variability and the trend in PONE appears consistent with the annual data. $\mathrm{C}$ - $\mathrm{IT}_{\text {July }}$ reconstructions from GYXO remained stable at c. $12{ }^{\circ} \mathrm{C}$ and do not show the changes seen in the instrumental record. Both GYXO and PONE show an increase in C-IC between AD 1970 and 1980, although C-IC values from GYXO reconstruct more maritime than expected throughout the record. All cores show changes in CCA scores since AD 1950, which coincides with a period of wetter weather in the instrumental record.

Based on the test proposed by Telford and Birks (2011), the

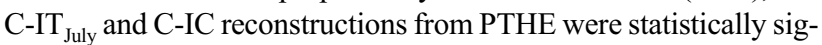
nificant when compared with reconstructions derived from random variables ( $p=0.032$ and 0.016 , respectively). Reconstructions from GYXO were not significant; however, C-IT July and C-IC reconstructions for the section of high amplitude change between 11.5 and $31 \mathrm{~cm}$ depth (3400-1600 cal. BP) were statistically significant ( $p=0.021$ and 0.046 , respectively). None of the reconstructions from the ${ }^{210} \mathrm{~Pb}$ dated sections of the three cores were statistically significant. The C-IC reconstructions from GYXO and PTHE and the C-IT $\mathrm{Iuly}_{\text {r }}$ reconstruction from PTHE show similar trends and magnitude of change to the instrumental record from Turuhansk. 


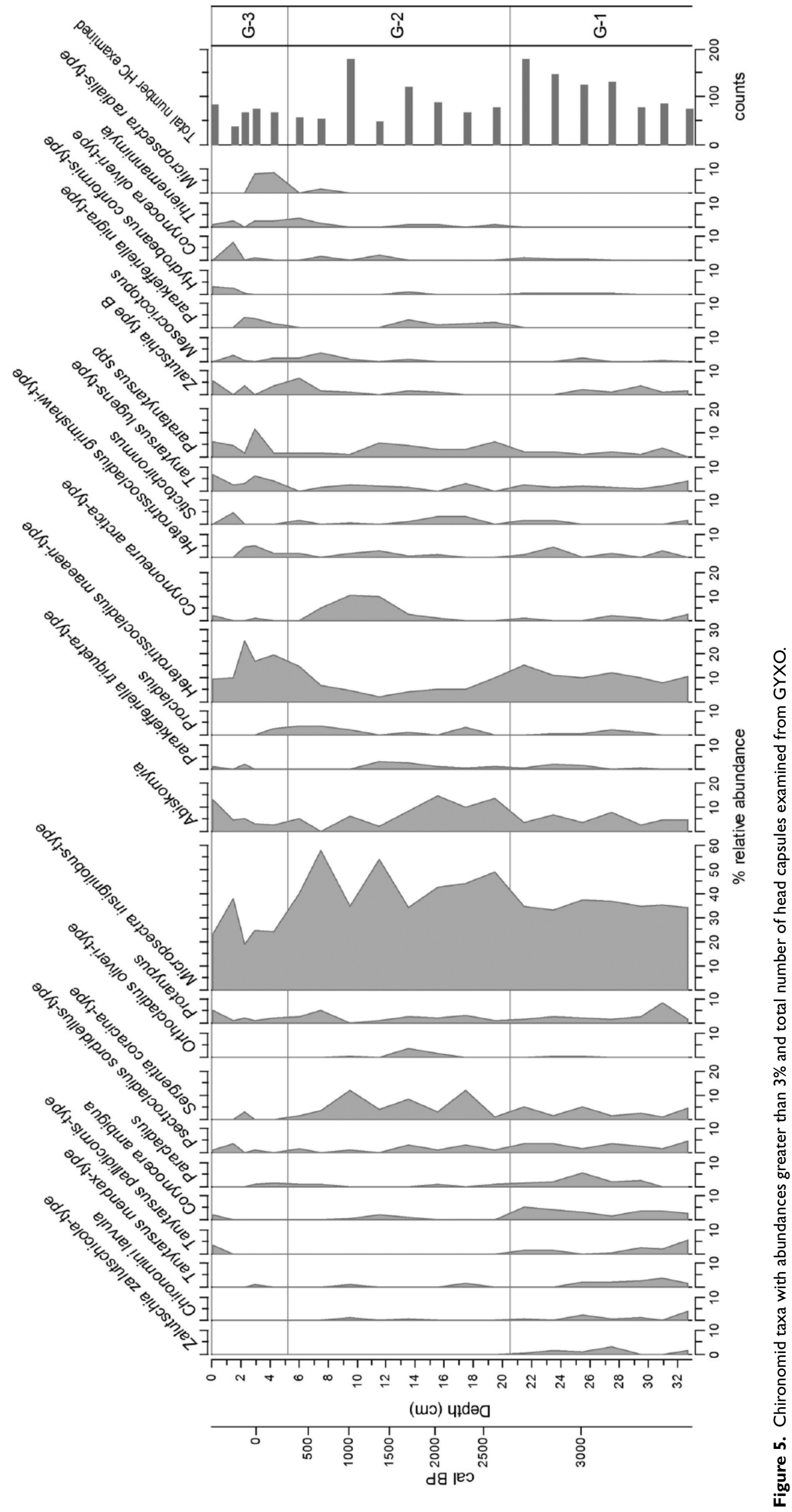



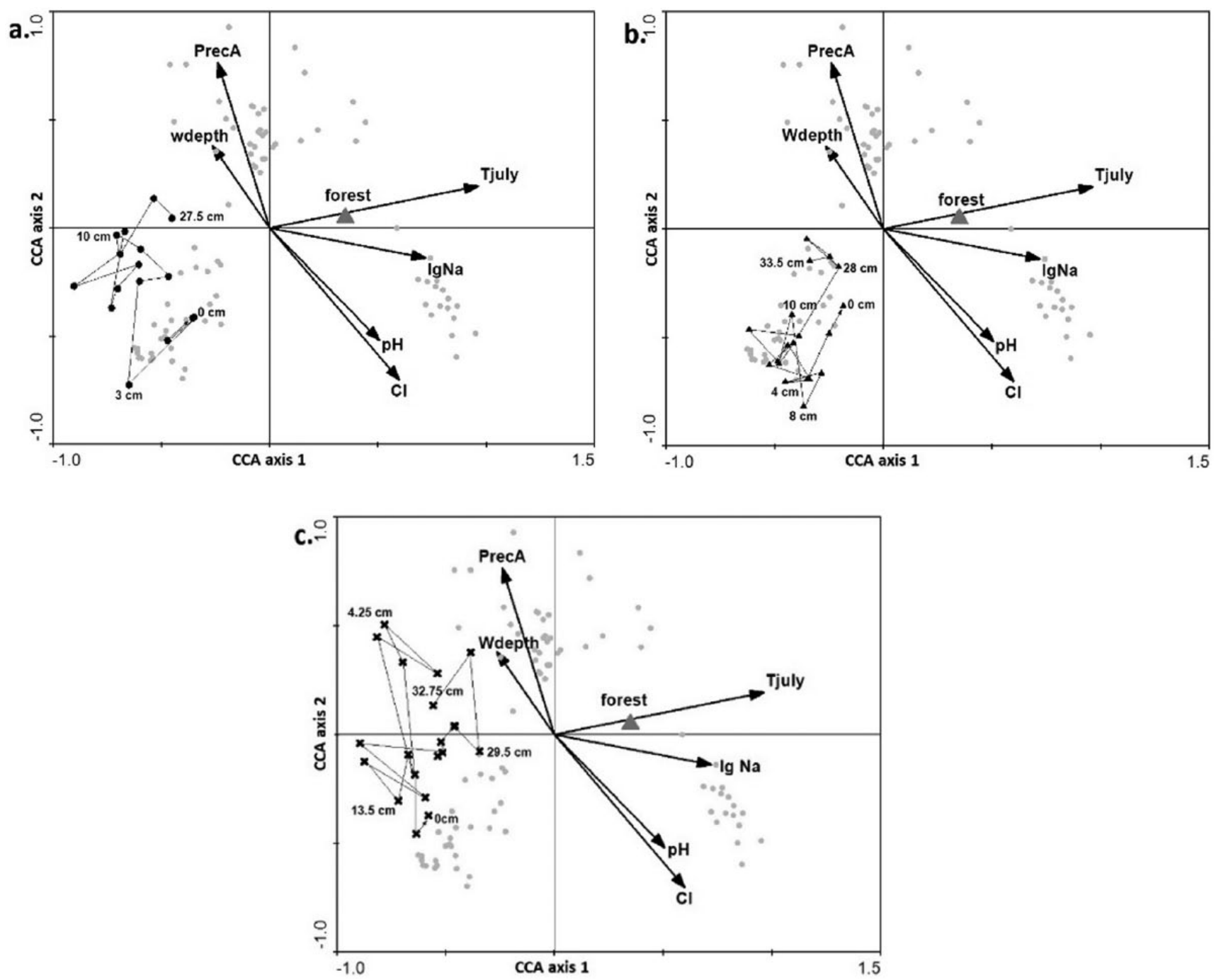

Figure 6. CCA plot of modern 8I lake Russian data set with (a) PONE, (b) PTHE and (c) GYXO plotted passively and joined as a time-track to show changes in chironomid assemblages in relation to significant lake chemical and physical variables (PrecA: mean annual precipitation; Wdepth: water depth; Tjuly: mean July air temperature; forest: presence of forest vegetation; $\lg \mathrm{Na}$ : log of sodium ion concentration $\mathrm{Cl}$ : continentality index and $\mathrm{pH}$ ).

\section{Discussion}

The analysis of short sediment cores retrieved from the Putorana lakes provides a unique opportunity to examine palaeoenvironmental and climatic change in this remote, poorly studied region of arctic Russia during the late Holocene. The analysis of chironomid assemblages in three neighbouring lakes also enables an assessment of whether the observed changes are site specific or of regional significance.

The chironomid fauna of the surface sediments from PONE, PTHE and other shallow Putorana lakes have high abundances of Corynocera ambigua and Corynocera oliveri-type with maximum abundances of $50.7 \%$ and $23.8 \%$, respectively (Self et al., 2011). This makes them distinct from modern assemblages in Norway and other lakes in north-east European Russia and western Siberia (Self et al., 2011). The co-occurrence of these Corynocera species with Chironomus anthracinus-type, Sergentia coracina-type, Procladius, Micropsectra spp., Tanytarsus lugens-type and other Tanytarsini species gives a faunal composition similar to early Holocene pioneer assemblages from northern Europe (Velle et al., 2005). This similarity may be because of the cool, continental climate and/or the oligotrophic status of the lakes, as many of these taxa, for example, Tanytarsus lugens, are found in the profundal of oligotrophic lakes or in the littoral of cold sub-arctic or sub-alpine lakes (Brodin, 1986; Brundin, 1956).

The ecology of Corynocera ambigua is enigmatic. Although absent from Britain today, the taxon is abundant in last interstadial and early Holocene sediments from Scotland (Brooks et al., 1997), Scandinavia (Velle et al., 2005), Switzerland (LarocqueTobler et al., 2010) and the Baltic region (Hofmann and Winn, 2000; Sarmaja-Korjonen et al., 2006). It occurs in various training sets as a cold stenotherm with a temperature optimum between $6^{\circ} \mathrm{C}$ and $12^{\circ} \mathrm{C}$ (Barley et al., 2006; Brooks and Birks, 2001; Larocque et al., 2006; Self et al., 2011). However, Brodersen and Lindegaard (1999) found the taxon at $0.5-25 \%$ abundance in surface sediments from warm, shallow, eutrophic lakes in Denmark and at approximately $75 \%$ abundance in Lake Stigsholm prior to AD 1888. They proposed that its disappearance from the Lake Stigsholm resulted, directly or indirectly, from a change in the biological structure of the lake from macrophyte-rich clear-water state to macrophyte-poor turbid state and associated changes in sediment structure, oxygen and food availability. At Egelsee, Switzerland, the disappearance of Corynocera ambigua corresponded with decreases in oligotrophic taxa and increases in eutrophic taxa (Larocque-Tobler et al., 2010). Its high abundance in the Putorana lakes may therefore reflect the pristine oligotrophic clear-water environment of the shallow Putorana lakes. 
(a)

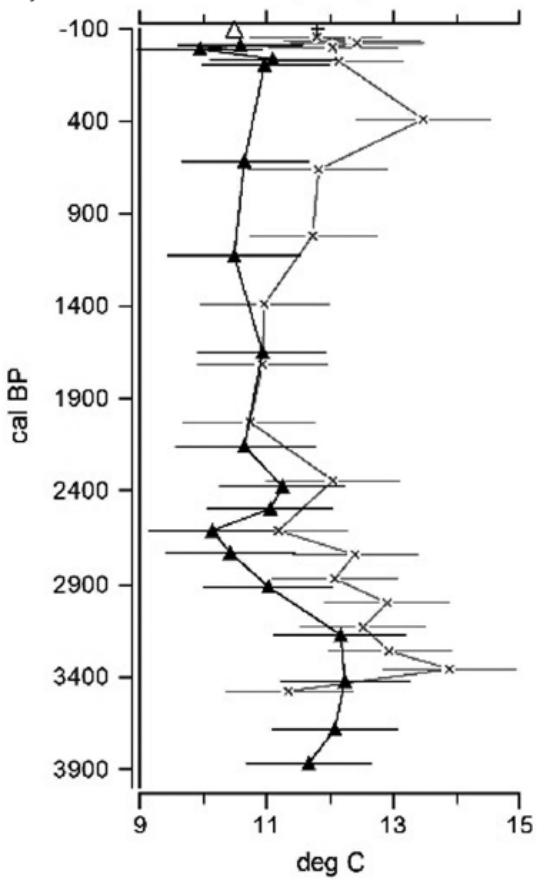

(b)

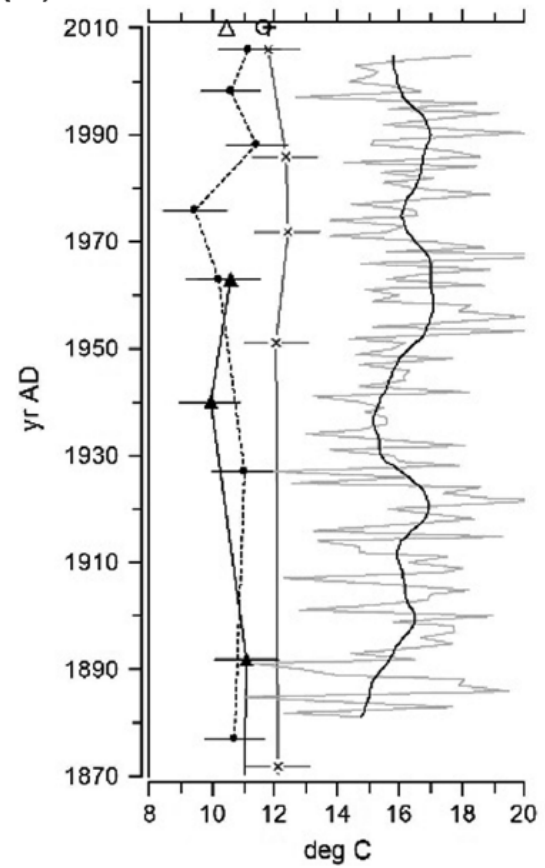

C-I July temperature

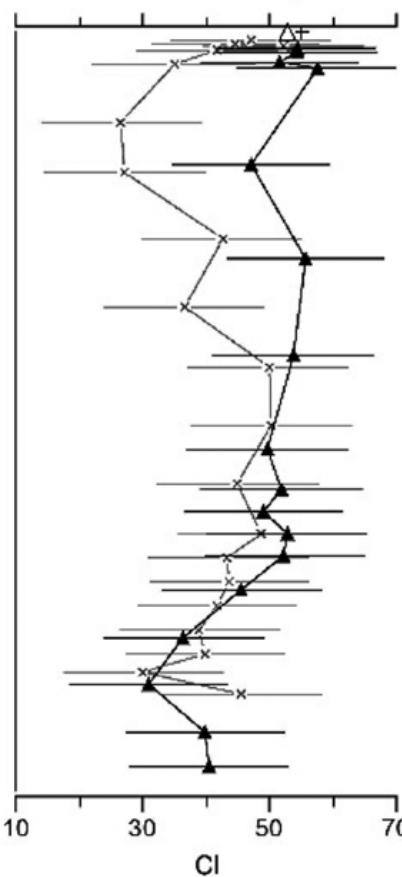

Cl

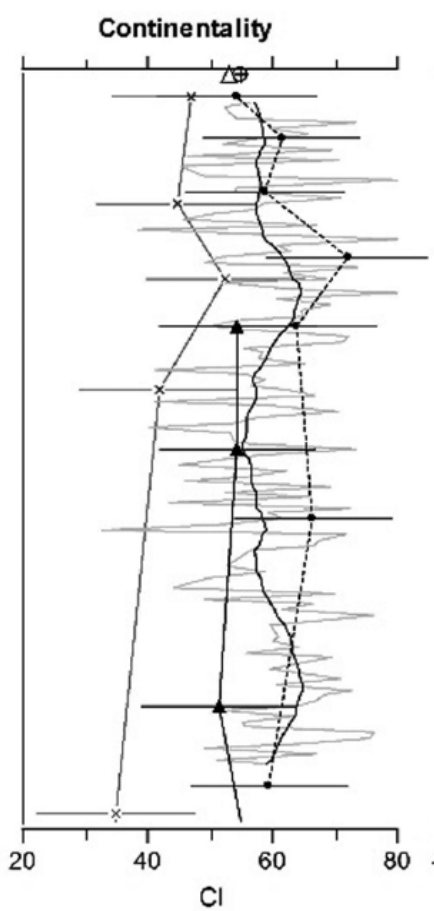

CCA axis 2

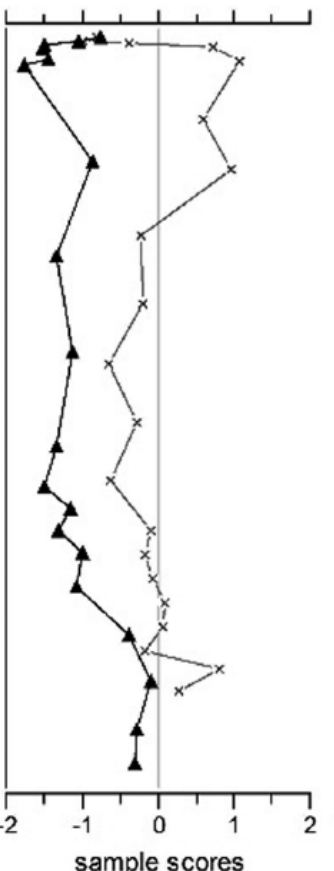

CCA axis 2

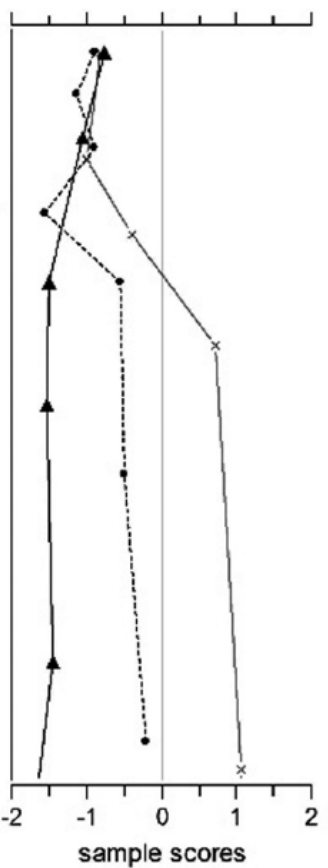

GISP2 [K+]

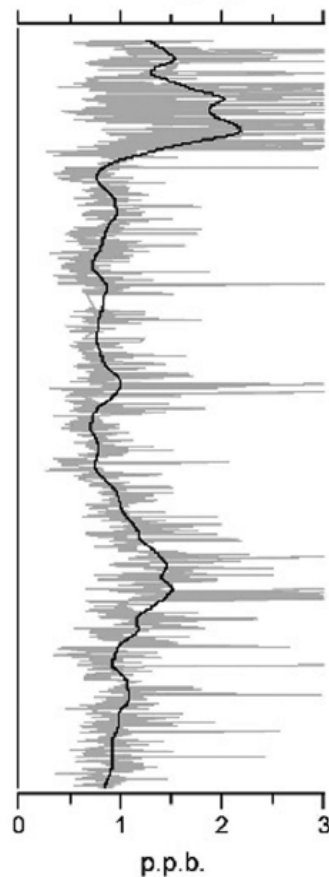

p.p.b.

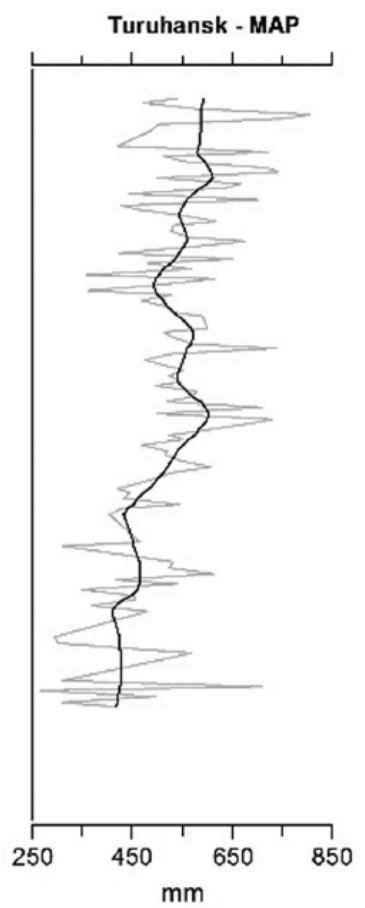

Figure 7. Summary diagram for PONE (๑), PTHE $(\boldsymbol{\Delta})$ and GYXO $(\mathrm{X})$ showing chironomid-inferred (C-I) July air temperatures, chironomidinferred (C-I) continentality indices and CCA axis 2 sample scores (a) over the past 4000 years with potassium ions concentration in the GISP2 ice core (Mayewski et al., 1997) and (b) over the past 130 years with instrumental July air temperatures, continentality indices and mean annual precipitation (MAP). Annual instrumental records from Turuhansk shown in grey with 0.15 smoother. Modern intrapolated values for July air temperature and continentality are shown on the upper x-axis PONE (O), PTHE ( $\Delta), \mathrm{GYXO}(+)$.

\section{Chironomid-inferred mean July air temperature and continentality reconstructions}

Analysis using the Telford and Birks (2011) method indicated that

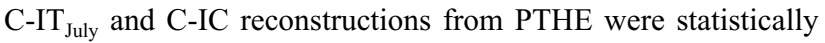
significant. Although reconstructions from GYXO were not significant for the entire core, reconstructions from the period 34001400 cal. BP were statistically significant, suggesting both lakes responded to larger shifts in climate. During other intervals, such as since $1400 \mathrm{cal}$. BP, the palaeoclimatic reconstructions should be interpreted with caution as the chironomid fauna in GYXO may also be responding to changes in lake and/or catchment processes. None of the reconstructions for the past 150 years were statistically significant, although they showed similar fluctuations to the meteorological record from Turuhansk. The Telford-Birks test determines whether the reconstruction explains a larger proportion of the variance in fossil data than $95 \%$ of 999 reconstructions of random environmental variables. The magnitude of the temperature and continentality fluctuations over the recent 150 years and the associated variability in the chironomid assemblages may be insignificant in comparison with the natural variability in the training set. Therefore, the test may not provide a 
reliable estimate of reconstruction reliability for time periods with low amplitude climate variability. Luoto et al. (2014) found that the increasing size of the training set increased the variability in the measured temperatures, so that reconstructions failed the Telford-Birks test, although the reconstructions were strongly and significantly correlated to reconstructions based on a smaller training set which passed. The Telford-Birks (2011) analyses tests the validity of the whole core, but the results suggest that for cores such as GYXO, that fail in some intervals of the sequence, the environmental variable to be reconstructed may be driving changes in other parts of the sequence and the reconstruction for these intervals may be valid.

Reconstructions from PTHE and GYXO suggest July temperatures were $1-2^{\circ} \mathrm{C}$ warmer with a more maritime climate than present (C-IC 30) c. 3400 cal. BP. In West Siberia, Arkhipov et al. (2005) showed that July and January temperatures show considerable latitudinal variability during this period (the SubBoreal thermal optimum). July temperatures at $55-56^{\circ} \mathrm{N}$ were close to their present-day values and reached values $2-3^{\circ} \mathrm{C}$ warmer north of $66^{\circ} \mathrm{N}$. Deviations in January temperature were smaller, from $0^{\circ} \mathrm{C}$ to $1^{\circ} \mathrm{C}$ warmer. Between 3200 and $2600 \mathrm{cal}$. $\mathrm{BP}, \mathrm{C}-\mathrm{IC}$ increased to $47-57$ and C-IT ${ }_{\text {July }}$ decreased by $1.8^{\circ} \mathrm{C}$ to $\sim 10^{\circ} \mathrm{C}$. Records throughout northern Eurasia show a general trend towards cooler summers c. 3500-2500 cal. BP and an associated southward migration of the treeline (Miller et al., 2010; Wanner et al., 2008). In the Pechora region of north-east European Russia, deforestation and summer cooling c. 3000 cal. BP (Kultti et al., 2004; Oksanen et al., 2001; Salonen et al., 2011) coincides with permafrost aggradation, dated to c. 3200-3000 cal. BP (Oksanen et al., 2001; Väliranta et al., 2003). In Siberia, the evidence is sparser; dated macrofossil remains suggest the treeline retreated on the Taymyr Peninsula and Lena River between 4000 and 3000 cal. BP (MacDonald et al., 2000) with establishment of the modern treeline by 2500 cal. BP (Kremenetski et al., 1998). Biochemical records from Lake Beloye, south-west Siberia, indicate a change to cooler and drier condition after 3400 cal. BP (Krivonogov et al., 2012), whereas pollen records from Lama Lake, further north on the Taymyr Peninsula, indicate cooling and higher precipitation began about $3100 \mathrm{cal}$. BP and continued until the sub-boreal/sub-atlantic boundary at $2500 \mathrm{cal}$. BP (Hahne and Melles, 1997). These earlier dates for cooling in Siberia may be part of a broader east-west trend as Oksanen (2005) found permafrost aggradation started in northern Russia c. $3000 \mathrm{cal}$. BP and in Fennoscandia c. 2500 cal. BP. Although declining summer insolation is believed to be the main driver of the Holocene summer temperature trend (Renssen et al., 2009; Wanner et al., 2008), Van Geel et al. (2000) suggested that cooling and glacier advance $c$. 2800-2900 cal. BP may be related to a decrease in solar activity. However, in PTHE and GYXO, cooling predates this solar minimum. Changes in these cores coincide with increases in the strength of Siberian High, shown by increasing $\mathrm{K}+$ deposition in the GISP2 ice core, and strengthening westerlies over the North Atlantic and Siberia (Meeker and Mayewski, 2002) which may indicate a change in atmospheric circulation.

From c. 2000 cal. BP, C-IT July and C-IC reconstructions and CCA axis 2 scores from GYXO and PTHE diverge (Figure 7a). While C-IT $\mathrm{July}_{\mathrm{y}}, \mathrm{C}-\mathrm{IC}$ and CCA scores remain relatively stable in PTHE until $1000 \mathrm{cal}$. BP, GYXO shows a general trend of increas-

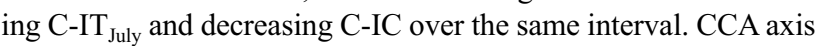
2 scores, associated with increasing water depth and MAP, for GYXO show wider fluctuations than those from PTHE which suggests GYXO may be more vulnerable to changes in lake or catchment hydrology. GYXO is situated in a large flat valley bottom, so increased spring melt-water, for example, may have resulted in flooding onto the extensive, low-lying wetlands adjacent to the present lake. A shallow littoral may warm more rapidly than deeper water or the lake may have become thermally stratified resulting in increased insensitivity to summer air temperatures. Berntsson et al. (2014) suggested catchment-related processes, such as increased catchment erosion, caused by enhanced precipitation overrode the July temperature signal in a similar depth lake in Sweden.

Between 1000 and 100 cal. BP, C-IT July reconstructions at PTHE remain relatively stable; however, C-IC decline and CCA axis 2 sample scores show a marked change at both PTHE and GYXO c. 600 cal. BP (Figure 7a). C-IT July $_{\text {reconstructions at }}$ GYXO also increase at this time. Sodium and potassium ion concentrations in the GISP2 ice core suggest there were major changes in atmospheric circulation c. 600 cal. BP (Mayewski et al., 2004; Meeker and Mayewski, 2002) with a transition from relatively weak to more intense winter and spring atmospheric circulation over the North Atlantic. Proxy records have identified a number of regional climate fluctuations during this period, with warm periods identified between 1100 and $800 \mathrm{cal}$. BP and between 760 and 700 cal. BP (Naurzbaev and Vaganov, 2000; Naurzbaev et al., 2002) followed by a cooler period (Andreev et al., 2002; Hantemirov and Shiyatov, 2002; Jacoby et al., 2000; Lubinski et al., 1999; Naurzbaev et al., 2002; Tarussov, 1992; Zeeberg et al., 2003). However, the records vary in the severity, timing and duration of the cold period. The pollen records from the Taymyr suggest $\mathrm{T}_{\text {July }}$ were approximately $1^{\circ} \mathrm{C}$ cooler between 550 and 300 cal. BP (Andreev et al., 2002), whereas the tree-ring growth in northern Siberia indicates June temperature was less than $0.5^{\circ} \mathrm{C}$ cooler from 600 to $300 \mathrm{cal}$. BP (Naurzbaev and Vaganov, 2000; Naurzbaev et al., 2002). Sediment cores suggest glacier advances on Novaya Zemlya occurred between 700 and 300 cal. BP (Zeeberg et al., 2003). Glacier advance probably resulted from an intensification of the winter Icelandic Low and spring Siberian High pressure systems (Mayewski et al., 2004; Meeker and Mayewski, 2002) resulting in cooler summer temperatures and increased precipitation. No fluctuations are evident

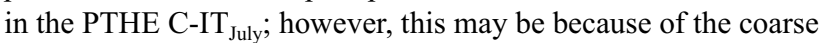

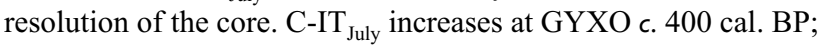
however, this is a single value and this section of the core did not pass the Telford-Birks test.

Radiocarbon dates from the basal section of PONE (14.5$27 \mathrm{~cm}$ ) suggested considerable disturbance of the sediment $c$. 1000-800 cal. BP, although the recent record indicates continuous deposition over the past 150 years. There is a decline in profundal taxa, such as Heterotrissocladius maeaeri-type and Stictochironomus, after $3.75 \mathrm{~cm}(-10 \mathrm{yr} \mathrm{BP})$, and they are absent from the most recent record (Figure 4). The abundance of taxa associated with flowing water, such as Rheocricotopus and Rheotanytarsus, steadily declines above $10 \mathrm{~cm}$ (approximately $100 \mathrm{yr}$ BP), and they are also absent from the recent record. These faunal changes are also evident in the time trajectory in CCA space (Figure 6), which shows a marked shift at this time from a deep-water to a shallow-water fauna. The maximum water depth at PONE during sampling was $5 \mathrm{~m}$. The morphometry of PONE is tightly constrained by the valley topography. The lake lies at the highest point of the valley floor and is currently fed by melt-water and has a single outflow stream which flows west along the valley (Figure 1b). The banks to the south and east are low ridges which separate the lake from the outflow of a large high-altitude lake which skirts the ridges and flows to the east. Therefore, the stream taxa present in PONE were probably allochthonous and washed into the lake during periods of high overland flow from the high-altitude lake. Between 750 and 150 cal. BP, decreases in orbitally driven Northern Hemisphere summer insolation, changes in atmospheric circulation, increased explosive volcanism, decreased solar luminosity and strong positive feedbacks led to expansion of the Arctic Ocean sea ice, regional glacier advances and increased terrestrial snow cover (Miller et al., 2010). Increases in the snow depth may have enhanced spring melt-water flooding at this time. 
The chironomid assemblage record from PONE suggests that between 800 and $100 \mathrm{cal}$. BP, the lake was subject to increases in water depth and influxes of allochthonous taxa, and after this date, the lake was predominately fed by melt-water. The chironomid assemblages from GYXO also suggest a period of deeper water than present-day during this period (Figures $6 \mathrm{c}$ and 7). Minor July temperature fluctuations are observed in the instrumental records and $\mathrm{C}_{-} \mathrm{IT}_{\text {July }}$ reconstructions from PONE and PTHE over the 20th century (Figure 7b). Between AD 1960 and

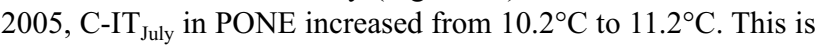
in agreement with observational data which show Arctic land surfaces warmed by $0.5^{\circ} \mathrm{C}$ per decade from AD 1979 (IPCC, 2013) and increases in permafrost temperatures of $0.3-2^{\circ} \mathrm{C}$ in the Russian European North since AD 1971 and $0.5-1.5^{\circ} \mathrm{C}$ in Northern Yakutia since early AD 1950s (Romanovsky et al., 2010). CCA axis 2 scores for all three cores remain relatively stable until $\mathrm{AD}$ 1950 , and recent changes coincide with a wetter phase shown in the instrumental record. River discharge into the Arctic Ocean increased over the 20th century (Peterson et al., 2002) and in northwest Canada. St Jacques and Sauchyn (2009) suggested increasing winter base flow and mean annual stream flow in rivers might result from melting permafrost. Therefore, increasing precipitation, evident in the instrumental record, and melting permafrost may have impacted the hydrology of the lakes in the study area resulting in sustained faunal changes. There are also significant increases in winter snow accumulation but a shorter snowmelt season in recent decades over Eurasia (Bulygina et al., 2009), which may increase localised flooding.

\section{Conclusion}

The short sediment cores retrieved from the Putorana lakes provide a rare opportunity to examine late Holocene palaeoenvironmental and climatic changes in this remote, poorly studied but climatically significant region of arctic Russia. The main conclusions are as follows:

- The composition of the chironomid fauna is similar to early Holocene pioneer assemblages from northern Europe. Corynocera ambigua and Corynocera oliveritype are dominant components in the fauna of the shallow lakes and their occurrence may reflect the pristine, clearwater conditions in these lakes.

- Chironomid-inferred July air temperatures and CIs from surface sediments at all three lakes are close to altitudecorrected values estimated from spatially interpolated meteorological records $\left(\mathrm{C}-\mathrm{IT}_{\text {July }}\right.$ within $0.5^{\circ} \mathrm{C}, \mathrm{C}-\mathrm{IC}$ within 1 at PONE and PTHE). C-IC reconstructs too maritime at GYXO, but shows consistent trends to the meteorological record.

- The chironomid-based reconstruction from PTHE suggest July temperatures were c. $1.5^{\circ} \mathrm{C}$ warmer with a more maritime climate than present between 3900 and $3200 \mathrm{cal}$. BP but cooled rapidly by c. $2^{\circ} \mathrm{C}$, with a more continental climate, c. 3000 cal. BP. These warmer and cooler intervals are similar in timing and scale to events in arctic Russian and other northern hemisphere records.

- Late $20^{\text {th }}$-century reconstructions from PONE suggest a period of warming over the past 50 years. All lakes also showed changes in CCA axis 2 scores over this interval, suggesting increased precipitation, enhanced permafrost melting and seasonal warming has resulted in marked faunal changes.

- Although the reconstructions from PONE were not statistically significant, the chironomid-inferred reconstructions show similar trends and magnitudes of changes as the meteorological record from Turuhansk. This suggests that despite the influence of changes in water depth or other environmental variables, the chironomid response to temperature is still evident and useful C-IT July estimates can be derived.

- The results suggest quantitative chironomid-based July temperature and continentality reconstructions at this location are more reliable from small catchment lakes than lakes in valleys where the hydrology and/or the water depth may be susceptible to change. This is particularly apparent in GYXO where changes in lake size, bathymetry and/or stratification of the lake appear to have masked any response to small-scale regional climate variability. However, major changes, such as a $2^{\circ} \mathrm{C}$ temperature decline c. 3000 cal. BP, are similar in scale and duration in both the PTHE and GYXO cores. Records from 'nonideal' environments may therefore provide useful records of Holocene climate fluctuations and testing different sections of the record using Telford and Birks (2011) may help to determine which sections show statistically significant responses to climate.

\section{Acknowledgements}

The sediment core was ${ }^{210} \mathrm{~Pb}$ dated by Handong Yang at the Bloomsbury Environmental Isotope Facility (BEIF) at University College London (UCL). Samples were radiocarbon-dated by Charlotte Bryant and staff at the NERC Radiocarbon Facility (Environment) and SUERC AMS Laboratory. Help with fieldwork was provided by Nadia Solovieva (UCL, UK), Mikhail Brezin and Elena Tkacheva (Moscow Zoo, Russia) and Vasily Ponomarev (Komi Science Centre, Russia). Arvid Odland (Telemark University College, Bø, Norway) provided altitudinal corrected temperature data for these lakes and the lakes in the Western Russia training set. The comments of two anonymous referees are also gratefully acknowledged.

\section{Funding}

The work by AS was funded by a NERC CASE studentship with the NHM (NER/S/A/2005/13227); additional funding was provided by CARBO-North funded under the EU Sixth Framework Programme Global Change and Ecosystems sub-programme (project number 036993). This work was supported by the NERC Radiocarbon Facility NRCF010001 (allocation number 1746.1013).

\section{References}

Andreev A, Siegert C, Klimanov V et al. (2002) Late Pleistocene and Holocene vegetation and climate on the Taymyr Lowland, Northern Siberia. Quaternary Research 57: 138-150.

Appleby PG (2001) Chronostratigraphic techniques in recent sediments. In: Last WM and Smol JP (eds) Tracking Environmental Change using Lake Sediments. Dordrecht: Kluwer Academic Publishers, pp. 171-203.

Arctic Climate Impact Assessment (ACIA) (2004) Impacts of a Warming Arctic: Arctic Climate Impact Assessment. Cambridge: Cambridge University Press.

Arkhipov SA, Volkova VS, Zolnikov LD et al. (2005) West Siberia. In: Wright HE Jr, Blyakharchuk TA, Velichko AA et al. (eds) Cenozoic Climatic and Environmental Changes in Russia (Geological Society of America Special Paper 382). Boulder, CO: The Geological Society of America, Inc., pp. 67-88.

Barley EM, Walker IR, Kurek J et al. (2006) A northwest North American training set: Distribution of freshwater midges in relation to air temperature and lake depth. Journal of Paleolimnology 36: 295-314.

Bekryaev RV, Polyakov IV and Alexeev VA (2010) Role of polar amplification in long-term surface air temperature variations and modern Arctic warming. Journal of Climate 23: 3888 3906. 
Bennett KD (1996) Determination of the number of zones in a biostratigraphical sequence. New Phytologist 132: 155-170.

Berntsson A, Rosqvist GC and Velle G (2014) Late-Holocene temperature and precipitation changes in Vindelfjällen, midwestern Swedish Lapland, inferred from chironomid and geochemical data. The Holocene 24: 78-92.

Blaauw M (2010) Methods and code for 'classical' age-modelling of radiocarbon sequences. Quaternary Geochronology 5: 512-518.

Brodersen KP and Lindegaard C (1999) Mass occurrence and sporadic distribution of Corynocera ambigua Zetterstedt (Diptera, Chironomidae) in Danish lakes. Neo- and palaeolimnological records. Journal of Paleolimnology 22: 41-52.

Brodersen KP, Odgaard BV, Vestergaard O et al. (2001) Chironomid stratigraphy in the shallow and eutrophic Lake Sobygaard, Denmark: Chironomid-macrophyte co-occurrence. Freshwater Biology 46: 253-267.

Brodin YW (1986) The postglacial history of Lake Flarken, southern Sweden, interpreted from subfossil insect remains. Internationale Revue der Gesamten Hydrobiologie 71: 371-432.

Bronk Ramsey C (2009) Dealing with outliers and offsets in radiocarbon dating. Radiocarbon 51: 1023-1045.

Brooks SJ (2006) Fossil midges (Diptera: Chironomidae) as palaeoclimatic indicators for the Eurasian region. Quaternary Science Reviews 25: 1894-1910.

Brooks SJ and Birks HJB (2001) Chironomid-inferred air temperatures from Late-glacial and Holocene sites in north-west Europe: Progress and problems. Quaternary Science Reviews 20: 1723-1741.

Brooks SJ, Langdon PG and Heiri O (2007) The Identification and Use of Palaearctic Chironomidae Larvae in Palaeoecology. London: Quaternary Research Association.

Brooks SJ, Mayle FE and Lowe JJ (1997) Chironomid-based Late-glacial climatic reconstruction for southeast Scotland. Journal of Quaternary Science 12: 161-167.

Brooks SJ, Axford Y, Heiri O et al. (2012) Chironomids can be reliable proxies for Holocene temperatures. A comment on Velle et al. (2010). The Holocene 22: 1495-1500.

Brundin L (1956) Zur Systematik der Orthocladiinae (Dipt., Chironomidae). Report of the Institute of Freshwater Research, Drottningholm, pp. 5-185.

Brundin L (1958) The bottom faunistical lake type system and its application to the southern hemisphere. Moreover a theory of glacial erosion as a factor of productivity in lakes and oceans. Verhandlungen der Interntionalen Vereinigung fur Theoretische und Angewandte Limnologie 13: 288-297.

Brundin L (1983) The larvae of Podonominae (Diptera: Chironomidae) of the Holarctic region - Keys and diagnoses. In: Wiederholm T (ed.) Chironomidae of the Holarctic Region: Keys and diagnoses, Part 1: Larvae (Entomologica Scandinavica Supplement No. 19). Lund: Entomological Society of Lund, Sweden, pp. 23-31.

Bulygina ON, Razuvaev VN and Korshunova NN (2009) Changes in snow cover over Northern Eurasia in the last few decades. Environmental Research Letters 4: 045026.

Cranston PS, Oliver DR and Saether OA (1983) The larvae of the Orthocladiinae (Diptera: Chironomidae) of the Holarctic region: Keys and diagnoses. In: Wiederholm T (ed.) Chironomidae of the Holarctic Region: Keys and Diagnoses, Part 1: Larvae (Entomologica Scandinavica Supplement No. 19). Lund: Entomological Society of Lund, Sweden, pp. 149-291.

Eggermont H and Heiri O (2012) The chironomid-temperature relationship: Expression in nature and palaeoenvironmental implications. Biological Reviews 87: 430-456.

Giesecke T, Bjune AE, Chiverrell RC et al. (2008) Exploring Holocene continentality changes in Fennoscandia using present and past tree distributions. Quaternary Science Reviews 27: 1296-1308.
Grieser J, Gommes R, Cofield S et al. (2006) Data Sources for FAO Worldmaps of Koeppen Climatologies and Climatic Net Primary Production. The Agromet Group, SDRN, Food and agriculture organization of the United Nations, Rome, August.

Hahne J and Melles M (1997) Late and post-glacial vegetation and climate history of the south-western Taymyr Peninsula, Central Siberia, as related by pollen analysis of a core from Lake Lama. Vegetation History and Archaeobotany 6: 1-8.

Hantemirov R and Shiyatov S (2002) A continuous multi-millennial ring-width chronology in Yamal, northwestern Siberia. The Holocene 12: 717-726.

Heiri O (2004) Within-lake variability of subfossil chironomid assemblages in shallow Norwegian lakes. Journal of Paleolimnology 32: 67-84.

Hofmann W and Winn K (2000) The littorina transgression in the Western Baltic Sea as indicated by subfossil Chironomidae (Diptera) and Cladocera (Crustacea). International Review of Hydrobiology 85: 267-291.

Huntley B (2012) Reconstructing palaeoclimates from biological proxies: Some often overlooked sources of uncertainity. Quaternary Science Reviews 31: 1-16.

IPCC (2013) Climate Change 2013: The Physical Science Basis. Contribution of Working Group I to the Fifth Assessment Report of the Intergovernmental Panel on Climate Change (ed Stocker TF, Qin D, Plattner G-K et al.). Cambridge: Cambridge University Press.

Jacoby GC, Lovelius NV, Shumilov OI et al. (2000) Long-term temperature trends and tree growth in the Taymir region of northern Siberia. Quaternary Research 53: 312-318.

Juggins S (1991) ZONE, version 1.2. Newcastle upon Tyne: University of Newcastle.

Kremenetski CV, Sulerzhitsky LD and Hantemirov R (1998) Holocene history of the northern range limits of some trees and shrubs in Russia. Arctic and Alpine Research 30: 317-333.

Krivonogov SK, Takahara H, Yamamuro M et al. (2012) Regional to local environmental changes in southern Western Siberia: Evidence from biotic records of mid to late Holocene sediments of Lake Beloye. Palaeogeography, Palaeoclimatology, Palaeoecology 331-332: 177-193.

Kultti S, Oksanen P and Väliranta M (2004) Holocene tree line, permafrost, and climate dynamics in the Nenets Region, East European Arctic. Canadian Journal of Earth Sciences 41: $1141-1158$.

Lang B, Brooks SJ, Bedford A et al. (2009) Regional consistency of Lateglacial chironomid-inferred temperatures from five sites in north-west England. Quaternary Science Reviews 29: $1528-1538$.

Larocque I, Hall RI and Grahn E (2001) Chironomids as indicators of climate change: A 100-lake training set from a subarctic region of northern Sweden (Lapland). Journal of Paleolimnology 26: 307-322.

Larocque I, Pienitz R and Rolland N (2006) Factors influencing the distribution of chironomids in lakes distributed along a latitudinal gradient in northwestern Quebec, Canada. Canadian Journal of Fisheries and Aquatic Sciences 63: 1286-1297.

Larocque-Tobler I, Heiri O and Wehrli M (2010) Late Glacial and Holocene temperature changes at Egelsee, Switzerland, reconstructed using subfossil chironomids. Journal of Paleolimnology 43: 649-666.

Lindegaard C (1995) Classification of water-bodies and pollution. In: Armitage P, Cranston PS and Pinder LCV (eds) The Chironomidae: The Biology and Ecology of Non-biting Midges. London: Chapman \& Hall, pp. 385-404.

Lotter AF, Heiri O, Brooks SJ et al. (2012) Rapid summer temperature changes during 1a: High-resolution multi-proxy climate 
reconstructions from Gerzensee (Switzerland). Quaternary Science Reviews 36: 103-113.

Lubinski D, Forman SL and Miller GH (1999) Holocene glacier and climate fluctuations on Franz Josef Land, Arctic Russia, $80^{\circ}$ N. Quaternary Science Reviews 18: 85-108.

Luoto TP, Kaukolehto M, Weckström J et al. (2014) New evidence of warm early-Holocene summers in subarctic Finland based on an enhanced regional chironomid-based temperature calibration model. Quaternary Research 81: 50-62.

MacDonald GM, Velichko AA, Kremenetski CV et al. (2000) Holocene treeline history and climate change across northern Eurasia. Quaternary Research 53: 302-311.

Mayewski PA, Meeker LD, Twickler MS et al. (1997) Major features and forcing of high-latitude northern hemisphere atmospheric circulation using a 110,000 year long glaciochemical series. Journal of Geophysical Research 102: 26345-26366.

Mayewski PA, Rohling EE, Stager J et al. (2004) Holocene climate variability. Quaternary Research 62: 243-255.

Meeker LD and Mayewski PA (2002) A 1400-year high-resolution record of atmospheric circulation over the North Atlantic and Asia. The Holocene 12: 257-266.

Miller GH, Brigham-Grette J, Alley RB et al. (2010) Temperature and precipitation history of the Arctic. Quaternary Science Reviews 29: 1679-1715.

Nalvikin DV (1973) The geology of the U.S.S.R (translated from the Russian by N. Rast). Edinburgh: Oliver and Boyd.

Naurzbaev MM and Vaganov EA (2000) Variation of early summer and annual temperatures in east Taymyr and Putoran (Siberia) over the last two millennia inferred from tree rings. Journal of Geophysical Research 105(D6): 7317-7326.

Naurzbaev MM, Vaganov EA, Sidorova OV et al. (2002) Summer temperatures in eastern Taimyr inferred from a 2427-year late-Holocene tree-ring chronology and earlier floating series. The Holocene 12: 727-736.

Nazarova L, Herzschuh U, Wetterich S et al. (2011) Chironomidbased inference models for estimating mean July air temperature and water depth from lakes in Yakutia, northeastern Russia. Journal of Paleolimnology 45: 57-71.

Oksanen PO (2005) Development of palsa mires on the northern European continent in relation to Holocene climatic and environmental changes. $\mathrm{PhD}$ Thesis, University of Oulu.

Oksanen PO, Kuhry P and Alekseeva RN (2001) Holocene development of the Rogovaya River peat plateau, European Russian Arctic. The Holocene 11: 25-40.

Peterson BJ, Holmes RM, McClelland JW et al. (2002) Increasing river discharge to the Arctic Ocean. Science 298: 21712173.

Pinder LCV and Morley DJ (1995) Chironomidae as indicators of water quality - With a comparison of the chironomid faunas of a series of contrasting Cumbrian Tarns. In: Harrington R and Stork NE (eds) Insects in a Changing Environment. London: Academic Press, pp. 272-293.

Pinder LCV and Reiss F (1983) The larvae of Chironominae (Diptera: Chironomidae) of the Holarctic region - Keys and diagnoses. In: Wiederholm T (ed.) Chironomidae of the Holarctic Region: Keys and Diagnoses, Part 1: Larvae (Entomologica Scandinavica Supplement No. 19). Lund: Entomological Society of Lund, Sweden, pp. 149-292.

Prowse TD, Wrona FJ, Reist JD et al. (2006) Climate changes effects on hydroecology of arctic freshwater ecosystems. Ambio 35: 347-358.

Przybylak R (2003) The Climate of the Arctic. Dordrecht: Kluwer Academic Publishers.

Quinlan R and Smol JP (2001) Chironomid-based inference models for estimating end-of-summer hypolimnetic oxygen from south-central Ontario shield lakes. Freshwater Biology 46: $1529-1551$
R Development Core Team (2013) R: A Language and Environment for Statistical Computing. Vienna: R Foundation for Statistical Computing. Available at: http://www.r-project.org.

Reimer PJ, Bard E, Bayliss A et al. (2013) IntCal13 and Marine13 radiocarbon age calibration curves, 0-50,000 years cal BP. Radiocarbon 55: 1869-1887.

Renberg I (1991) The HON-Kajak sediment corer. Journal of Paleolimnology 6: 167-170.

Renssen H, Seppä H, Heiri O et al. (2009) The spatial and temporal complexity of the Holocene thermal maximum. Nature Geoscience 2: 411-414.

Rieradevall M and Brooks SJ (2001) An identification guide to subfossil Tanypodinae larvae (Insecta: Diptera: Chironomidae) based on cephalic setation. Journal of Paleolimnology 25: 81-99.

Romanovsky VE, Drosdov DS, Oberman NG et al. (2010) The thermal state of permafrost in Russia. Permafrost and Periglacial Processes 21: 136-155.

Salonen JS, Seppä H, Luoto M et al. (2012) A North European pollen-calibration set: Analysing the climatic responses of a biological proxy using novel regression tree methods. Quaternary Science Reviews 45: 95-110.

Salonen JS, Seppä H, Väliranta M et al. (2011) The Holocene thermal maximum and late-Holocene cooling in the tundra of NE European Russia. Quaternary Research 75: 501-511.

Sarmaja-Korjonen K, Nyman M, Kultii S et al. (2006) Paleolimnological development of Lake Njagajavri, northern Finnish Lapland, in a changing Holocene climate and environment. Journal of Paleolimnology 35: 65-81.

Self AE, Brooks SJ, Birks HJB et al. (2011) The distribution and abundance of chironomids in high-latitude Eurasian lakes with respect to temperature and continentality: Development and application of new chironomid-based climate-inference models in northern Russia. Quaternary Science Reviews 30: 1122-1141.

Shahgedanova M (2002) Climate at present and in the historical past. In: Shahgedanova M (ed.) The Physical Geography of Northern Eurasia. Oxford: Oxford University Press, pp. 70-102.

Shahgedanova M, Perov V and Mudrov Y (2002) The mountains of Northern Russia. In: Shahgedanova M (ed.) The Physical Geography of Northern Eurasia. Oxford: Oxford University Press, pp. 284-313.

St Jacques J-M and Sauchyn D (2009) Increasing winter baseflow and mean annual streamflow from possible permafrost thawing in the Northwest Territories, Canada. Geophysical Research Letters 36: LO1401

Strenzke K (1950) Systematik, Morphologie und Ökologie der terrestrischen Chironomiden. Archiv für Hydrobiologie, Supplement 18: 207-414.

Tarussov A (1992) The Arctic: From Svalbard to Severnaya Zemlya climate reconstructions from ice-cores. In: Bradley RS and Jones PD (eds) Climate since 1550. London: Routledge, pp. 505-516.

Telford RJ (2011) palaeoSig: Significance Tests of Quantitative Palaeoenvironmental Reconstructions. R package version 1.0.

Telford R and Birks HJB (2011) A novel method for assessing the significance of quantitative reconstructions inferred from biotic assemblages. Quaternary Science Reviews 30: 1272-1278.

Ter Braak CJF and Smilauer P (2002) CANOCO Reference Manual and User's Guide to CANOCO for Windows: Software for Canonical Community Ordination Version 4.5. Ithaca, NY: Microcomputer Power.

Väliranta M, Kaakinen A and Kuhry P (2003) Holocene climate and landscape evolution East of the Pechora Delta, East-European Russian Arctic. Quaternary Research 59: 335-344.

Van Geel B, Heusser C, Renssen H et al. (2000) Climatic change in Chile at around $2700 \mathrm{BP}$ and global evidence for solar forcing: A hypothesis. The Holocene 10: 659-664. 
Velle G, Brodersen KP, Birks HJB et al. (2010) Midges as quantitative temperature indicator species: Lessons for palaeoecology. The Holocene 20: 989-1002.

Velle G, Brodersen KP, Birks HJB et al. (2012) Inconsistent results should not be overlooked: A reply to Brooks et al. (2012). The Holocene 22: 1501-1508.

Velle G, Brooks SJ, Birks HJB et al. (2005) Chironomids as a tool for inferring Holocene climate: An assessment based on six sites in southern Scandinavia. Quaternary Science Reviews 24: $1429-1462$.

Walker IR and Cwynar LC (2006) Midges and palaeotemperature reconstruction - The North American experience. Quaternary Science Reviews 25: 1911-1925.
Wanner H, Beer J, Butikofer J et al. (2008) Mid- to Late Holocene climate change: An overview. Quaternary Science Reviews 27: 1791-1828.

Webber JP and Klein DR (1977) Geobotanical and ecological observations at two locations in the west-central Siberian Arctic. Arctic and Alpine Research 9: 305-315.

Wiederholm T (1983) Chironomidae of the Holarctic Region: Keys and Diagnoses, Part 1: Larvae (Entomologica Scandinavica Supplement No. 19). Lund: Entomological Society of Lund, Sweden.

Zeeberg J, Forman SL and Polyak L (2003) Glacier extent in a Novaya Zemlys fjord during the 'Little Ice Age' inferred from glaciomarine sediment records. Polar Research 22: 385-394. 
Reproduced with permission of the copyright owner. Further reproduction prohibited without permission. 